\title{
Pelatihan Pembelajaran Al-Qur'an Mahasiswa Penjaskesrek Dengan 7 Lagu Tilawah Pada Program Iklim Zikir Hari Jum'at STKIP Taman Siswa Bima
}

\author{
Salahudin*, Muhammad, Shutan Arie Shandi \\ STKIP Taman Siswa, Bima, Indonesia \\ *Coresponding Author: salahudin3009@gmail.com \\ Dikirim: 16-12-2021; Direvisi: 21-12-2021; Diterima: 02-01-2022
}

\begin{abstract}
Abstrak: Pelatihan ini berangkat dari gemarnya program iklim zikir yang dilakukan oleh kampus STKIP Taman siswa bima, Lagu yang di gunakan adalah lagu dalam Tilawah. Selain itu mahasiswa penjaskesrek tersebut mempunyai prestasi dalam bidang Tilawatil Qur'an dan mewujudkan kampus yang beradab serta memiliki skil. Pelatihan pembelajaran membaca alQur'an dengan lagu tilawah adalah proses belajar dan mengajar antara guru dan peserta didik untuk mencapai tujuan berupa membaca al-Qur'an dengan lagu-lagu tilawah Qur'an yang terdiri dari lagu Bayyati, lagu Shoba, lagu Hijas, lagu Nahawan, lagu Sika, lagu Rasta Alan Nawa, lagu Jiharka, lagu Banjaka, dan lagu Bayyati yang diadakan di luar jam perkuliahan. Jenis penelitian lapangan (field research) yang bersifat kualitatif deskriptif. mengambil lokasi penelitian di STKIP Taman siswa bima. Pengumpulan data dengan menggunakan metode observasi, wawancara dan dokumentasi. Pengumpulan data dilakukan dengan menggali sumber dari ketua prodi penjaskesrek, dan guru pembelajaran Tilawah Qur'an. Analisis yang digunakan dengan reduksi data, penyajian data dan kesimpulan. Hasil penelitian menunjukkan pembelajaran membaca al-Qur'an dengan lagu tilawah pada mahasiswa penjaskesrek materi yang digunakan adalah makro tilawah Q.S al-Baqarah: 1-7 dengan sistem yang diterapkan adalah klasikal dan individual, metode demonstrasi, metode drill, metode sorogan, metode ceramah, dan metode pemberian tugas. Lagu yang dipelajari adalah lagu Tilawah bayyati, hijaz, nahawan, dan rost. Evaluasi dilaksanakan setiap jum'at dalam bentuk pre test dan evaluasi harian.
\end{abstract}

Kata Kunci: Pelatihan Membaca Al-Qur'an; 7 Lagu Tilawah

\begin{abstract}
This training departs from the fondness of the remembrance climate program conducted by the STKIP Taman bima campus. The song used is a song in recitations. In addition, these physical and social education students have achievements in the field of Tilawatil Qur'an and create a civilized and skilled campus. Training for learning to read the Koran with recitations is a learning and teaching process between teachers and students to achieve the goal of reading the Koran with Koran recitations consisting of Bayyati songs, Shoba songs, Hijas songs, Nahawan's song, Sika's song, Alan Nawa's Rasta song, Jiharka's song, Banjaka's song, and Bayyati's song which are held outside class hours. The type of field research (field research) is descriptive qualitative. took the research location at STKIP Taman Siswa bima. Collecting data using the method of observation, interviews and documentation. Data collection was carried out by digging sources from the head of the Physical Education Study Program, and the teacher of learning Qur'an recitations. The analysis used is data reduction, data presentation and conclusions. The results showed that learning to read the Koran with recitations for physical education students, the material used was macro recitations of QS al-Baqarah: 1-7 with the system applied was classical and individual, demonstration method, drill method, sorogan method, lecture method, and the assignment method. The songs studied were recitation of bayyati, hijaz, nahawan, and rost songs. Evaluation is carried out every Friday in the form of pre-test and daily evaluation.
\end{abstract}

Keywords: Training; Learning; Reciting Al-Qur'an; 7 Recitation Songs 


\section{PENDAHULUAN}

Pelatiahan pembelajaran al-qur'an dengan 7 lagu tilawah berbeda dengan istilah pengajaran, perbedaannya terletak pada orientasi subjek yang difokuskan, dalam istilah pengajaran guru merupakan subjek yang lebih berperan aktif dalam kegiatan belajar mengajar, sedangkan pembelajaran memfokuskan pada peserta didik. Untuk memahami hakikat pembelajaran dapat dilihat dari dua segi, yaitu dari segi bahasa (etimologis) dan istilah (terminologis). Secara bahasa, kata pembelajaran merupakan terjemahan dari bahasa Inggris, instruction yang bermakna sederhana, upaya untuk membelajarkan seseorang atau kelompok orang, melalui berbagai upaya dan berbagai strategi, metode dan pendekatan ke arah pencapaian tujuan yang telah direncanakan.

Salah satu aspek pendidikan agama yang kurang mendapat perhatian adalah pendidikan membaca Al-Qur'an. Pada umumnya orang tua lebih menitik beratkan pada pendidikan umum saja dan kurang memperhatikan pendidikan agama termasuk pendidikan membaca Al-Qur'an. Sebagai langkah awal adalah meletakkan dasar agama yang kuat pada anak sebagai persiapan untuk mengarungi hidup dan kehidupannya. Dengan dasar agama yang kuat, maka setelah menginjak dewasa akan lebih arif dan bijaksana dalam menentukan sikap, langkah dan keputusan hidupnya karena pendidikan agama adalah jiwa (spiritualitas) dari pendidikan. (Wakit \& Agustin, 2020)

Sesungguhnya syariat Islam adalah dari Allah SWT pencipta seluruh alam dan termasuk manusia di dalamnya. Konsekuensi bagi kaum muslimin adalah menerima al-Qur'an secara lengkap dan seutuhnya sebagai pedoman hidup. Umat Islam berpegang teguh baik pada ucapan maupun perbuatan baik atas pribadi, keluarga, masyarakat, organisasi maupun Negara. Pengertian membaca secara etimologis sama dengan dalam arti "menghimpun" huruf-huruf dan kata-kata (sehingga memperoleh pengertian). Pengertian membaca di sini tidak harus membaca tulisan yang tertulis, atau tidak memerintahkan umat untuk membaca hanya al-Qur'an dan hadits Nabi saw, tetapi lebih luas dari itu, bacalah alam berkembang ini, untuk memperoleh keyakinan tentang adanya si pencipta dan untuk dimanfaatkan sebesar-besarnya bagi kepentingan umat demi meningkatkan kesejahteraan mereka, bukan untuk menimbulkan permusuhan sehingga masing-masing pihak berusaha menghancurkan pihak lain.

Para ulama, dahulu dan sekarang, menaruh perhatian besar terhadap Tilawah (cara membaca al-Qur'an sehingga pengucapan lafazh-lafazh al-Qur'an menjadi baik dan benar. Pengembangan dan pembinaan Tilawatil Qur'an dibeberapa daerah termasuk mahasiswa STKIP Taman siswa bima prodi penjaskesrek terkendala dengan sangat minimnya ustaz/guru yang menguasai ilmu seni baca al-Qur'an sehingga seorang ustaz/guru yang memiliki kemampuan seni baca al-Qur'an menjadi sesuatu yang mahal dan langka. Untuk mengundangnya memerlukan perencanaan waktu dan biaya yang tinggi. Apalagi ustaz/guru yang sudah kelas propinsi maupun nasional. Para guru Pendidikan Agama Islam (PAI) dan juga para penyuluh Pendidikan Agama Islam yang diharapkan bisa mengajarkan Tilawatil Qur'an juga terkendala sangat sedikit yang mempunyai kemampuan mengajarkan tilawah. Di sisi lain para ustaz/guru yang mempunyai kemampuan seni baca alQur'an, banyak diantara mereka yang tidak paham lagu-lagu tilawah dan tidak bisa mengikuti perkembangan variasi lagu sehingga lagunya terkesan ketinggalan zaman. 


\section{KAJIAN TEORI}

Pembelajaran membaca al-Qur'an dengan lagu Tilawatil Qur'an adalah proses belajar dan mengajar antara guru dan peserta didik untuk mencapai tujun berupa membaca al-Qur'an dengan lagu-lagu dalam Tilawatil Qur'an (Nurhayanti, 2018).

Pembelajaran pada hakikatnya adalah suatu proses, yaitu proses mengatur, mengorganisasi lingkungan yang ada di sekitar peserta didik sehingga dapat menumbuhkan dan mendorong peserta didik melakukan proses belajar. Pembelajaran juga dikatakan sebagai proses memberikan bimbingan atau bantuan kepada peserta didik dalam melakukan proses belajar. Peran dari guru sebagai pembimbing bertolak dari banyaknya peserta didik yang bermasalah. Dalam belajar tentunya banyak perbedaan, seperti adanya peserta didik yang mampu mencerna materi pelajaran, ada pula peserta didik yang lambah dalam mencerna materi pelajaran. Kedua perbedaan inilah yang menyebabkan guru mampu mengatur strategi dalam pembelajaran yang sesuai dengan keadaan setiap peserta didik. Oleh karena itu, jika hakikat belajar adalah "perubahan", maka hakikat pembelajaran adalah "pengaturan (Pane \& Darwis Dasopang, 2017), a perbuatan belajar terjadi karena interaksi seseorang dengan lingkungannya yang akan menghasilkan sesuatu perubahan tingkah laku pada berbagai aspek, diantaranya, sikap, dan keterampilan. Perubahan-perubahan yang terjadi didasari oleh individu yang belajar, berkesinambungan dan akan berdampak pada fungsi kehidupan lainnya. Selain itu perubahan bersifat positif , terjadi karena peran aktif dari pembelajar, tidak bersifat sementara, bertujuan, dan perubahan yang terjadi meliputi keseluruhan tingkah laku pada sikap, keterampilan, pengetahuan, dan sebagainya (Arieska, 2019).

Pelatihan merupakan salah satu upaya perusahaan untuk meningkatkan kinerja karyawannya agar mereka dapat bekerja dengan baik dan dapat memberikan kualitas pelayanan yang baik pula kepada pelanggan (Pyrolysis, 2012). Pelatihan merupakan kompetensi dari pendidikan proses belajar di mana tujuan tersebut yaitu membantu mencapai tujuan organisasi dan meningkatkan keterampilan secara softskill maupun hardskill yang berlaku dalam waktu yang relatif singkat, dengan metode yang lebih mengutamakan praktek dari pada teori. Proses yang dilaksanakan sesuai dengan tujuan organisasi, program pelatihan menyediakan para karyawan dengan pengetahuan yang spesifik dan dapat diketahui serta keterampilan yang dapat di gunakan dalam lapangan pekerjaan (Mangkunegara, 2014)

\section{METODE PELAKSANAAN KEGIATAN}

Tahap pesiapan

\section{a. Tahap Persiapan}

Tahap persiapan dilakukan dengan menghubungi pengolola dewan kesatuan masjid STKIP Taman siswa bima untuk menjelaskan tujuan kegiatan yang akan dilaksanakan yaitu pelatihan pembelajaran al-qur'an dengan 7 lagu tilawah pada mahasiswa penjaskesrek yang kurang memahami tata cara membaca al-qu'an dengan lagu tilawah. Koordinasi antara pelaksana PKM dan pengelola masjid dan prodi pnjaskesrek mengahsilkan beberapa kesepakatan terkait dengan jadwal pelaksanaan, tempat kegiatan, materi pelatihan, dan metode penyampaiannya.

b. Tahap Pelaksanaan

Tahap pelakanaan dilakukan dengan diawali pemberian arahan kepada pihak mahasiswa penjaskesrek. Selanjutnya semua pihak dalam kegiatan ini yaitu 
Pelaksana PKM, Pengelola masjid dan semua mahasiswa yang ada di STKIP Taman siswa bima. Selanjutnya pengelola masjid membuka kegiatan dan selanjunya kami memimpin kegiatan pelatihannya. Saat kegiatan ini dibantu oleh pelaksana PKM dan pelatih pembelajaran al-qur'an dengan 7 lagu tilawah. Selama kegiatan ini bahasa yang digunakan bersifat komunikatif yaitu bahasa yang digunakan sehari-hari. Pendekatan bahasa daerah ini terbukti mampu menghidupkan suasana penyuluhan sehingga diskusi berlangsung aktif dan kekeluargaan. Selajutnya setelah bersama membaca al-qur'an dengan lagu tilawah. Tahap selanjutnya adalah pengelola dan pelaksana PKM membimbing mahasiswa untuk berusaha membiasakan membaca alqur'an dengan lagu tilawah yang sudah latih berulang-ulang hingga 5 kali dalam satu lagu. Lagu yang digunakan dalam pembelajaran ini yaitu Lagu-lagu pokok dalam seni baca al-Qur'an dibagi menjadi sembilan, yaitu: lagu Bayyati, lagu Shoba, lagi Hijas, lagu Nahawan, lagu Sika, lagu Rasta Alan Nawa, lagu Jiharka, lagu Banjaka, dan lagu Bayyati penutup. Namun, yang lazim dipakai di Indonesia ada tujuh macam, yaitu: lagu Bayyati, lagu Shoba, lagu Hijas, lagu Nahawan, lagu Sika, lagu Rasta Alan Nawa, dan lagu Jiharka.

\section{IMPLEMENTASI KEGIATAN DAN PEMBAHASAN}

Pelatihan pembelajaran membaca al-Qur'an dengan 7 lagu tilawah ini dilakukan di masjid al-berkah sudirman di kumpulkan beberapa mahasiswa seperti yang ada dalam gambar dibawah ini:.

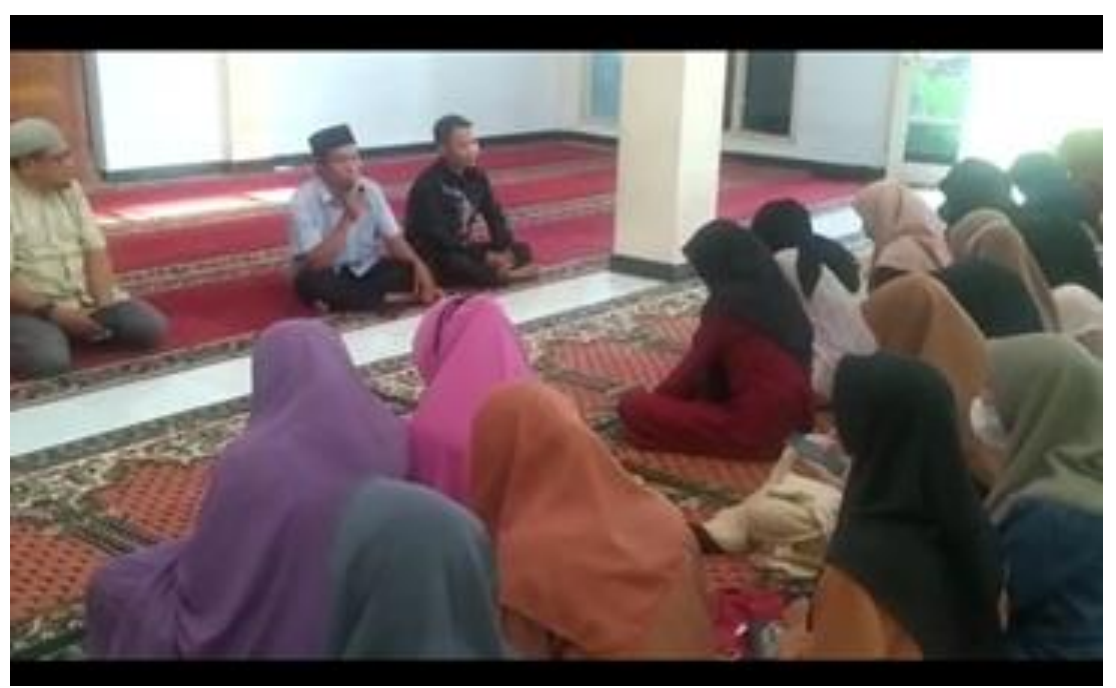

Gambar 1. Proses pelatihan

Pelatihan ini pembelajaran tilawah yang digunakan dalam pembelajaran ini yaitu Lagu-lagu pokok dalam seni baca al-Qur'an dibagi menjadi sembilan, yaitu: lagu Bayyati, lagu Shoba, lagi Hijas, lagu Nahawan, lagu Sika, lagu Rasta Alan Nawa, lagu Jiharka, lagu Banjaka, dan lagu Bayyati penutup. Namun, yang lazim dipakai di Indonesia ada tujuh macam, yaitu: lagu Bayyati, lagu Shoba, lagu Hijas, lagu Nahawan, lagu Sika, lagu Rasta Alan Nawa, dan lagu Jiharka. Pelatihan yang dilakukan dengan saubjek mahasiswa penjaskesrek 17 orang dan dilakukan tes awal dan tes akhir setelah perlakuan latihan pelajaran dengan lagu tilawah seperti yang ada di tabel dibawah ini: 
Tabel 1. Pre tes dan Pos tes

\begin{tabular}{|c|c|c|c|}
\hline No. peserta & Pre tes & Pos tes & Meningkat \\
\hline 001 & 45 & 70 & $\sqrt{ }$ \\
\hline 002 & 63 & 85 & $\sqrt{ }$ \\
\hline 003 & 55 & 75 & $\sqrt{ }$ \\
\hline 004 & 60 & 80 & $\sqrt{ }$ \\
\hline 005 & 63 & 75 & $\sqrt{ }$ \\
\hline 006 & 67 & 90 & $\sqrt{ }$ \\
\hline 007 & 56 & 67 & $\sqrt{ }$ \\
\hline 008 & 70 & 78 & $\sqrt{ }$ \\
\hline 009 & 45 & 65 & $\sqrt{ }$ \\
\hline 010 & 55 & 65 & $\sqrt{ }$ \\
\hline 011 & 50 & 60 & $\sqrt{ }$ \\
\hline 012 & 65 & 70 & $\sqrt{ }$ \\
\hline 013 & 50 & 50 & $\checkmark$ \\
\hline 014 & 45 & 60 & $\sqrt{ }$ \\
\hline 015 & 45 & 45 & $\checkmark$ \\
\hline 016 & 58 & 65 & $\sqrt{ }$ \\
\hline 017 & 60 & 80 & $\sqrt{ }$ \\
\hline
\end{tabular}

Tabel 1 di atas menunjukkan bahwa terjadi peningkatan pengetahuan pada peserta pelatihan. Hal tersebut ditunjukkan oleh sebanyak 15 peserta memiliki skor post test yang meningkat dari skor pre-test. Dengan kata lain terdapat sebesar $88,23 \%$ peserta mengalami peningkatan pada pembacaan al-qur'an dengan 7 lagu tilawah, sedangkan sisanya sebesar $11,76 \%$ belum meningkat.

\section{KESIMPULAN}

Berdasarkan pembahasan hasil penelitian yang berjudul "Pelatihan pembelajaran Membaca Al-Qur'an Dengan Lagu tilawah pada mahasiswa penjaskesrek, Tilawatil Qur'an di program iklim zikir kampus STKIP Taman Siswa Bima" dapat disimpulkan bahwa pembelajaran membaca al-Qur'an dengan lagu tilawah dalam iklim zikir Tilawatil Qur'an di STKIP Taman siswa bima materi yang digunakan adalah makro tilawah Q.S al-Baqarah: 1-7 dengan sistem yang diterapkan adalah klasikal dan kelompok, metode demonstrasi, metode drill/latihan, dengan metode talaqqi, dan metode pemberian tugas. Lagu yang dipelajari adalah lagu Tilawah bayyati, hijaz, nahawan, dan rost. Evaluasi dalam pembelajaran membaca al-qur'an dengan lagu tilawah dilaksanakan setiap hari dalam bentuk pre test yang bertujuan untuk memperlancar bacaan siswa dan harian untuk kenaikan ayat selanjutnya. Bentuk evaluasi dibuat sesuai dengan penilaian yang biasa dilakukan dalam perlombaan mengingat target diadakan ekstrakurikuler Tilawatil Qur'an adalah prestasi dalam bidang tersebut dan tujuan yang hendak dicapai dalam pembelajaran Tilawatil Qur'an adalah Tartil membaca al-Qur'an.

\section{UCAPAN TERIMA KASIH}

Tim Pengabdian Kepada Masyarakat Prodi Penjaskesrek menghaturkan banyak terima kasih kepada Mahasiswa prodi penjaskesrek STKIP Taman Siswa Bima yang sudah berpartisipasi sebagai peserta dan bekerjasama untuk melakukan kegiatan pengabdian kepada masyarakat yang berupa pelatihan pembelajaran Al-Qur'an 
dengan 7 lagu tilawah. Tidak terkecuali, Tim Pengabdian Kepada Masyarakat prodi penjaskesrek

\section{DAFTAR PUSTAKA}

Mangkunegara, A.P., 2014. (2014). Pengaruh Pelatihan Dan Penempatan Kerja Terhadap Kinerja Karyawan Pada Pt. Bank Bjb Kantor Cabang Utama Bandung. Journal of Chemical Information and Modeling, 53(9), 1689-1699.

Arieska, R. (2019). Pembelajaran Seni Baca Al-Qur`An di Ukm Hiqma UIN Raden Intan Lampung. Molecules, 9(1), 148-162.

Nurhayanti, N. I. M. O. K. I. (2018). Pembelajaran Membaca Al-Qur'an Dengan Lagu Tilawah Dalam Ekstrakurikuler Tilawatil Qur'an Di Mi Nurul Ulum Lebeng Kecamatan Sumpiuh Kabupaten ....

Pane, A., \& Darwis Dasopang, M. (2017). Belajar Dan Pembelajaran. FITRAH:Jurnal Kajian Ilmu-ilmu Keislaman, 3(2), 333. https://doi.org/10.24952/fitrah.v3i2.945

Pyrolysis, F. (2012). Pengaruh Yang Signifikan antara Metode Pelatihan, Materi Pelatihan, Trainer terhadap Efektivitas Pelatihan Otomotif Pada UPT BLK Dinas Sosial Tenaga Kerja dan Transmigrasi Kabupaten Kudus. 5-27.

Wakit, S., \& Agustin, D. (2020). Pelatihan Pembelajaran Al- Qur ' an Dengan Menggunakan Metode Qiro ' ati Di Madrasah Diniah Darul Ulum Mumbulsari Jember. Jurnal Pengabdian Masyarakat Ipteks, 6(1), 28-33. 